\title{
PORTUGUÊS COMO SEGUNDA LÍNGUA: CONTRIBUIÇÓES PARA A IMPLANTAÇÃO DE UM PROGRAMA DE ENSINO BILÍNGUE PARA SURDOS, DE ROBERVAL TEIXEIRA E SILVA
}

Fernanda Moraes D’Olivo

Fundação Técnico Educacional Souza Marques, FTESM, Rio de Janeiro, RJ, Brasil

Como ensinar Português para alunos que não conhecem essa língua? Qual metodologia utilizar? Quem são esses alunos, já falantes de outras línguas, que irão aprender Português? Essas indagaçóes, primordiais de serem feitas quando se ensina Português como segunda língua - ou L2 são, muitas vezes, deixadas de lado quando esses alunos são surdos ${ }^{1}$. Tais questôes, no entanto, são norteadoras do trabalho de doutorado de Roberval Teixeira e Silva que, apesar de ter sido realizado em 2004, traz contribuiçóes relevantes quanto à concepçáo de língua, de surdez e de metodologias de ensino de Português voltadas para surdos, constituindo-se como um estudo precursor da área.

Seu trabalho tem como objetivo construir "um olhar reflexivo e socialmente significativo sobre a surdez" (SILVA, 2004, p. 12) sob uma perspectiva sociointeracional do discurso (GOFFMAN, 1959; GRICE, 1975; GUMPERZ, 1982; TANNEN, 1984; RIBEIRO; GARCEZ, 1998). Para isso, sua tese é organizada em três eixos fundamentais, são eles: (i) uma visão antropológica de surdez e da LIBRAS enquanto primeira língua - L1 - para o surdo; (ii) uma visão crítica sobre a língua escrita e seu processo de ensino/aprendizagem; e (iii) uma reflexáo acerca do português ensinado como segunda língua. Esse percurso é fundamental para o desenvolvimento

\footnotetext{
${ }^{1}$ Tese orientada pela Profa. Dra. Maria Carmelita Pádua Dias, defendida em 2004, na Pontifícia Universidade Católica, Rio de Janeiro.

${ }^{2}$ As nomenclaturas "primeira língua" e "segunda língua" foram utilizadas pelo autor da tese com base nos estudos de Altenhofen (2002) - que apresenta uma distinção entre língua materna e primeira língua - e Heye e Savedra (1995) - que distinguem o conceito de segunda língua (aprendida em situação de comunicação natural) e língua estrangeira (adquirida em ambiente de sala de aula).
} 
de sua reflexão, bem como para o encaminhamento que dá a suas análises, que tem como corpus redaçóes produzidas por alunos surdos do Centro Educacional Pilar Velazquez (CEPV), localizado na cidade do Rio de Janeiro, em diferentes etapas do processo de aquisição da Língua Portuguesa.

É de extrema relevância nesse estudo o fato de que todas as análises, assim como as reflexôes teóricas, são constituídas a partir do olhar de professor de Português como segunda língua. Um olhar cuidadoso que considera a língua do outro nesse processo. E justamente por considerar a cultura e a língua do outro nesse processo que Silva busca situar sua pesquisa, já no capítulo 2 de sua tese, na interface entre língua, cultura, sociedade e minorias linguísticas. Dentro de tal perspectiva, ressalta a relevância de se tomar a LIBRAS como a primeira língua dos surdos, fazendo, assim, uma crítica aos discursos - principalmente discursos médicos - que muitas vezes inferiorizam essa língua em prol da exclusiva oralização do surdo. $\mathrm{O}$ autor mostra, de forma enfática, que ao apagar a LIBRAS como língua primeira do surdo, apaga-se também a possibilidade desse sujeito se constituir como tal dentro de sua própria língua. Assim, ao considerar a LIBRAS como língua natural para os surdos, segundo Silva, se está garantindo-lhes o direito de serem letrados a partir dela. Como nas próprias palavras do autor, o surdo, por meio da LIBRAS, "pode narrar-se a si mesmo dentro de sua própria língua, pode finalmente existir socialmente com suas marcas, valores, criatividade, humor" (SILVA, 2004, p. 35-36). O grande trabalho do pesquisador, nesse capítulo, foi apresentar uma visão política acerca da língua, ressaltando que o Português deve ser tomado como segunda língua para os surdos.

É com esse olhar que o autor constrói o seu percurso teórico no capítulo seguinte, apresentando, no processo de aprendizagem da língua escrita, a diferença entre letramento e alfabetização, bem como a diferença entre letramento autônomo e letramento ideológico, elegendo para a sua discussão, este último, a partir das leituras dos trabalhos de Kleiman (1995; 1998). No decorrer desse capítulo, mostra, de forma clara, que o surdo experiencia o processo de letramento diferentemente do ouvinte, já que não tem a instrumentalização da língua oral. Nesse sentido, o autor ressalta que o processo pelo qual o surdo passa ao aprender a escrever a Língua Portuguesa não é a alfabetização, mas sim o aprendizado de uma segunda língua, mostrando sempre em seu texto a importância de se considerar a cultura surda, assim como a sua língua primeira, a LIBRAS, nesse processo de aprendizagem. É fundamental, para a perspectiva adotada por Silva em seu trabalho de tese, o conceito de Letramento Ideológico, que considera 
que todas as práticas de letramento, além de serem aspectos da cultura, também fazem parte de estruturas de poder da sociedade, reforçando assim a perspectiva que o autor toma a língua, considerando-a dentro de uma relação de poder no âmbito social.

Tendo em vista o fato de que ensinar Português para o surdo é ensinálo como segunda língua, o autor apresenta, no quarto capítulo $O$ português como segunda língua: descrição e ensino, compreendendo a concepção de língua a partir da vertente da sociolinguística interacional, que orienta e sustenta seu trabalho de pesquisa, assim como suas práticas como professor de Português como segunda língua. Nessa vertente, a língua é analisada sempre em uso na e pela sociedade. Deve-se, assim, considerar a língua em seu processo de interaçáo com o outro, sempre a tomando também como objeto cultural. É a partir dessa perspectiva que Silva, em sua tese, mostra que se deve ensinar a segunda língua ao outro tendo sempre como ponto de partida não a forma, a estrutura da língua, mas sim o seu uso, já que os sentidos presentes no código linguístico dependem do contexto em que são inseridos. $\mathrm{O}$ pesquisador salienta que esse aspecto precisa ser ressaltado na formação de professores de português como segunda língua. Um outro ponto relevante desse capítulo é o modo como o autor apresenta a possibilidade de se ensinar a língua tendo como foco o uso e não a forma. Para isso, ele mostra como é possível ensinar o uso dos tempos e modos verbais a partir de gêneros textuais, como o relato, por exemplo, considerando, nesse processo de ensino/aprendizagem, aspectos discursivos-pragmáticos do Português do Brasil. Silva finaliza esse capítulo reforçando o fato de que se aprende uma língua em situaçóes concretas de uso, e, nesse sentido, não se deve focar na estrutura da língua, mas sim na "construção do saber escolher e usar essas estruturas" (SILVA, 2004, p. 73), possibilitando a constituição de um aprendizado pautado na língua sempre em seu contexto de uso e levando em conta a sua função social.

Após essa construção teórica, no qual apresenta suas consideraçôes acerca de língua, surdez, língua escrita e aspectos do Português como segunda língua, o autor analisa, a partir do seu olhar de professor de Português nesse campo de atuaçáo, como destacado anteriormente, os textos produzidos pelos alunos surdos do CEPV, entre os anos de 2003 e 2004. Nessas análises, salienta a relevância de se ensinar o letramento da Língua Portuguesa escrita ao aluno surdo, como por exemplo o fato de que se escreve da esquerda para a direita e de que se iniciam os parágrafos com letra maiúscula, bem como de lançar um olhar de professor de Português como segunda língua nos textos escritos, que vê a L1, no caso, a LIBRAS, 
atravessada nesse processo de aprendizagem da L2. A partir da concepção de língua apresentada no capítulo 4, o autor, em suas análises, mostra que o processo de aprendizagem do Português como L2 se sustenta em três grandes movimentos no desenvolvimento da escrita do surdo: organização gráfico-visual; aspectos da organização do significado e aspectos relativos à apropriação da gramática. Tendo em vista toda a discussão apresentada nas análises, o que ficou fortemente marcado nesse capítulo foi o fato de que foi possível compreender que "se o ouvinte vai organizando o mundo da escrita através da sua língua, o surdo vai, também e necessariamente, passar por fases diferentes de elaboração do que é a escrita por meio de seu conhecimento de língua de sinais" (SILVA, 2004, p. 93).

O autor finaliza o seu trabalho reforçando a importância de sustentar o ensino de Português como segunda língua para o surdo, tendo a concepçáo de língua enquanto interação social, pois, no processo de ensino/ aprendizagem, é importante ter em mente que para o aluno surdo só fará sentido aprender Português se ele tiver o que dizer nessa língua.

Considerando toda a discussão apresentada ao longo da tese de Roberval Teixeira e Silva, se pode considerá-la um texto de extrema relevância no cenário científico e pedagógico voltado para o ensino de Português para surdos. Ela pode e deve ser tomada como ponto direcionador de discussóes acerca de como ensinar Português para surdos, tendo sempre um olhar para a LIBRAS enquanto L1. É um trabalho, portanto, fundamental para professores de Português para surdos, bem como para a formação de futuros professores. 